\title{
Penerapan Data Mining Untuk Potensi Promo Penjualan Tiket Menggunakan Basket Algoritma
}

\author{
Andi Supriadi Chan \\ Dosen Sistem Informasi Universitas Putera Batam Kepri \\ J1. R soeprapto Muka Kuning, Batam \\ chakadoang@gmail.com
}

Submitted: 10-10-2017, Reviewed: 26-10-2017, Accepted 03-11-2017

http://dx.doi.org/10.22202/jei.2017.v4i1.2532

\begin{abstract}
ABSTRAK
keberhasilan dalam menjalankan bisnis tidak bergantung pada bagaimana cara menjalankan bisnis, akan tetapi pada bagaimana menjalankannya jika dibandingkan dengan lainnya. Kunci untuk membuat perbedaan terletak pada pemakaian data yang tersimpan Proses untuk menguraikan penemuan pengetahuan di dalam database seperti yang dilakukan untuk melihat keterkaitan penjualan antar item yang jika dapat dikelola dalam proses bisnis, akan memberikan nilai positif bagi peningkatan kinerja proses bisnis tersebut yang berujung pada peningkatan keuntungan dari bisnis tersebut Perusahaan - perusahaan yang bergerak pada bidang tour travel kota batam dalam mengembangkan usaha yang dimiliki sangat memerlukan pengolahan data dalam jumlah besar untuk melakukan promo penjualan tiket dan hotel.hal tersebut berkaitan dengan jumlah pengunjung kota batam yang sangat tinggi, perusahaan yang menjadi travel agen dapat mengembangkan bisnis ticketing dan voucer hotel dengan cara memberikan promo sehingga dapat menarik wisatawan untuk membeli secara langsung maupun online. Penerapan metode basket algoritma pada teknik Data Mining dengan menggunakan algoritma Apriori sangat efisien dan dapat mempercepat proses pembentukan kecenderungan pola kombinasi itemset hasil penjualan tiket pada PT.Bandar madani 165 untuk promosi penjualan, yaitu dengan support dan confidence tertinggi adalah Sriwijaya dan lion serta Batik dan Lion dengan nilai support $40 \%$ dan confidence $80 \%$. Dengan Penerapan data mining dengan menggunakan metode basket algoritma dengan apriori dapat sangat berguna dalam membantu perusahaan dalam memberikan promosi dalam penjualan tiket sehingga dapat meningkatkan pendapatan perusahaan serta keuntungan dari promosi yang diberikan kepada pelanggan
\end{abstract}

Kata kunci:Data Mining, Tiket, apriori, wisata,travel.

\begin{abstract}
success in running a business does not depend on how to run a business, but on how to run it when compared to others. The key to making a difference lies in the use of stored data The process for describing the discovery of knowledge in the database as done to see the linkage of sales between items that, if managed in the business process, will provide a positive value for the improvement of business process performance that led to increased profits of these businesses Companies engaged in the field of travel tour batam city in developing the business owned is in need of processing large amounts of data to conduct ticket and hotel sales promo.hal is related to the number of visitors to the city of batam is very high, the company being a travel agents can develop business ticketing and voucher hotel by giving promo so that it can attract tourists to buy directly or online. The application of basketball algorithm method in Data Mining technique using Apriori algorithm is very efficient and can accelerate the process of formation of trend of itemset combination result of ticket sales at PT.Bandar madani 165 for sales promotion, that is with the highest support and confidence are Sriwijaya and lion and Batik and Lion with a support value
\end{abstract}


of $40 \%$ and an $80 \%$ confidence. With the application of data mining using basketball algorithm with a priori method can be very useful in assisting companies in providing promotions in ticket sales so as to increase corporate earnings as well as the benefits of promotions provided to customers.

Keywords : data mining, ticket, apriori,tour,travel

\section{PENDAHULUAN}

Cara yang mudah untuk memastikan apakah makalah sesuai dengan format yang ditentukan adalah dengan menggunakan dokumen ini sebagai acuan. Bapak/Ibu hanya perlu memindahkan isi dari makalah yang sudah ditulis ke dalam dokumen ini. Makalah ini menggunakan spasi $1 \mathrm{~cm}$. Judul bab harus ringkas dan diberikan nomor secara berurutan dengan menggunakan sistem decimal untuk subbab. Kata asing harus ditulis dalam bentuk italic dan dianjurkan tidak digunakan terlalu banyak.

Di era global sekarang ini yang ditandai dengan perubahan-perubahan pesat pada kondisi perekonomian secara keseluruhan, hal ini menimbulkan suatu tuntutan yang harus dipenuhi oleh pelaku ekonomi maupun industri. Bisnis tidak berjalan pada ruang tertutup. Oleh karena itu keberhasilan dalam menjalankan bisnis tidak bergantung pada bagaimana cara menjalankan bisnis, akan tetapi pada bagaimana menjalankannya jika dibandingkan dengan lainnya. Kunci untuk membuat perbedaan terletak pada pemakaian data yang tersimpan (Sugandi, 2013)

Hasil utama dari pengolahan data tersebut yaitu kemampuan untuk memrediksi fakta lingkungan bisnis. Hal ini membuat kita mampu melakukan tindakan proaktif dibandingkan hanya reaktif. Data memberikan pengetahuan tak ternilai tentang masa depan. Data membantu kita mengoperasikan bisnis secara optimal, yaitu dengan cara mengembangkan market share, meningkatkan customer share, dan membangun loyalitas. (Singkil, 2015)

Proses untuk menguraikan penemuan pengetahuan di dalam database seperti yang dilakukan untuk melihat keterkaitan penjualan antar item yang jika dapat dikelola dalam proses bisnis, akan memberikan nilai positif bagi peningkatan kinerja proses bisnis tersebut yang berujung pada peningkatan keuntungan dari bisnis tersebut.

Perusahaan - perusahaan yang bergerak pada bidang tour travel kota batam dalam mengembangkan usaha yang dimiliki sangat memerlukan pengolahan data dalam jumlah besar untuk melakukan promo penjualan tiket dan hotel.hal tersebut berkaitan dengan jumlah pengunjung kota batam yang sangat tinggi,berdasarkan data BPS kota batam , jumlah wisatawan mancanegara yang berkunjung ke kota batam saja pada tahun 2015 mencapai 1,454 Juta orang (BPS Batam) belum lagi wisatawan yang berasal dari Indonesia sendiri.

Dengan besarnya jumlah wisatawan yang datang maupun pergi ke kota batam ini, perusahaan yang menjadi travel agen dapat mengembangkan bisnis ticketing dan voucer hotel dengan cara memberikan promo sehingga dapat menarik wisatawan untuk membeli secara langsung maupun online.tetapi kendala dalam melakukan promo yang tepat seringkali bermasalah, baik dari ketidakpastian musim liburan maupun kebiasaan masyarakat dalam melakukan kunjungan ke kota batam.

Ditambah lagi belum adanya pengolahan data dalam jumlah besar yang dimiliki oleh perusahaan yang bergerak di bidang travel agen untuk memprediksi bagaimana tren penjualan kedepannya,sehingga data transaksi yang pernah dilakukan perusahaan tersimpan sia-sia tanpa dapat diolah kembali untuk digunakan oleh perusahaan ,hal itu menjadi kerugian tersendiri untuk perusahaan,padahal dengan data transaksi dalam jumlah besar yang dimiliki perusahaan dapat dimanfaatkan sehingga dapat memberikan keuntungan yang sangat besar.

Oleh karena itu, penelitian ini mengusulkan metode penilaian Data mining menggunakan metode Market basket analysis yang dilakukan pada PT.Bandar Madani Kota 
Batam Implementasian ini dilakukan berdasarkan data penjualan 2 bulan terakhir. Sehingga diharapkan dengan Melakukan penilaian potensi promosi pada PT. Bandar madani Batam serta Menerapkan metode market basket analisi dalam menganalisa potensi pemberian promo yang tepat dapat meningkatkan keuntungan dan menghasilkan informasi yang akurat terhadap kapan pemberian promo yang tepat pada PT bandar madani batam.

\section{LANDASAN TEORI \\ 2.1 Data Mining}

Menurut Gartner Group,data mining adalah proses menemukan hubungan baru yang mempunyai arti, pola dan kebiasaan dengan memilah-milah sebagian besardata yang disimpan dalam media penyimpanan dengan menggunakan teknologi pengenalan pola seperti teknik statistic dan matematika. Data mining merupakan gabungan dari beberapa disiplin ilmu yang menyatukan teknik dari pembelajaran mesin, pengenalan pola, statistik, database, dan visualisasi untuk penanganan permasalahan pengambilan informasi dari database yang besar(Chan, 2018).

Data mining akan melihat data dari sudut yang berbeda pada waktu yang sama. Hal ini mencegah pengabaian atribut yang terlihat tidak relevan. Data mining akan mencari interdependensi antara atribut yang memungkinkan ekstraksi semua informasi yang relevan dari data, walaupun tersembunyi dalam kombinasi beberapa atribut (Aldeen, Salleh, \& Razzaque, 2015).

Menurut Turban dalam bukunya yang berjudul "Decision Support Systems and Intelligent Systems", data mining adalah suatu istilah yang digunakan untuk menguraikan penemuan pengetahuan di dalam basis data. Data mining adalah proses yang menggunakan teknik statistik, matematika, kecerdasan buatan, dan machine learning untuk mengekstraksi dan mengidentifikasi informasi yang

bermanfaat dan pengetahuan yang terkait dari berbagai basis data besar.(Gunadi \& Sensuse, 2012)

langkah-langkah penting dalam proses penambangan pengetahuan dari data secara umum sebagai berikut :

1. Pembersihan data (data cleaning), yaitu proses menghapus data pengganggu (noise) yang dikatakan tidak konsisten atau tidak diperlukan.

2. Integrasi data (data integration), yaitu menggabungkan berbagai sumber data.

3. Pemilihan data (data selection), yaitu memilih data yang dipilih sesuai kebutuhan analisis.

4. Transformasi data (data transformation), yaitu proses transformasi data ke dalam format untuk diproses dan siap ditambang.

5. Penggalian data (data mining), yaitu menerapkan metode kecerdasan untuk ekstraksi pola.

6. Evaluasi pola (pattern evaluation), yaitu mengidentifikasi pola-pola yang menarik yang merepresentasikan pengetahuan.

7. Penyajian pola (knowledge presentation), yaitu teknik untuk memvisualisasikan pola pengetahuan ke pengguna.

Data mining membantu perusahaan atau organisasi untuk mendapatkan pola dari data-data yang tersimpan di dalam basis data perusahaan. Pengetahuan yang diperoleh tersebut akan menjadi pedoman dalam mengambil tindakan-tindakan bisnis sebagai upaya pemeliharaan dan peningkatan tingkat kompetitif bisnis perusahaan. Walaupun sudah banyak perangkat lunak yang menawarkan kemampuan dalam proses data mining, keterlibatan manusia sangat dibutuhkan dalam setiap fase proses data mining itu sendiri. Pemahaman terhadap model statistik dan matematik yang digunakan dalam perangkat lunak sangat dituntut (Aghdam, Kamalpour, Chen, Tze, \& Sim, 2013).

Data mining adalah kegiatan menemukan pola yang menarik dari data dalam jumlah besar, data dapat disimpan dalam database, data warehouse, atau penyimpanan informasi lainnya. Data mining berkaitan dengan bidang ilmu-ilmu lain, seperti database sistem, data warehousing, 
statistik, machine learning, information retrieval, dan komputasi tingkat tinggi. Selain itu, data mining didukung oleh ilmu lain seperti neural network, pengenalan pola, spatial data analysis, image database, signal processing. Data mining didefinisikan sebagai proses menemukan pola-pola dalam data. Proses ini otomatis atau seringnya semiotomatis. Pola yang ditemukan harus penuh arti dan pola tersebut memberikan keuntungan, biasanya keuntungan secara ekonomi (Data et al., 2014).

\subsection{Market Basket Analysis}

Market Basket Analysis merupakan sebuah analisis terhadap kebiasaan customer berbelanja pada supermarket dengan cara menemukan asosiasi dan korelasi di antara berbagai macam item yang dimasukkan customer di dalam shopping basket mereka. Secara lebih spesifik Market Basket Analysis bertujuan untuk mengetahui item apa saja yang sering dibeli bersamaan oleh customer. item di sini diartikan sebagai berbagai macam produk atau barang pada supermarket (Magister, Gunadarma, Studi, Sistem, \& Guandarma, 2009)

\subsection{Promosi}

Promosi adalah upaya untuk memberitahukan atau menawarkan produk atau jasa pada dengan tujuan menarik calon konsumen untuk membeli atau mengkonsumsinya. Dengan adanya promosi produsen atau distributor mengharapkan kenaikannya angka penjualan.(Arief, Widyawan, \& Sunafri Hantono, 2012)

Tujuan promosi di antaranya adalah:

1. Menyebarkan informasi produk kepada target pasar potensial

2. Untuk mendapatkan kenaikan penjualan dan profit/laba

3. Untuk mendapatkan pelanggan baru dan menjaga kesetiaan pelanggan

4. Untuk menjaga kestabilan penjualan ketika terjadi lesu pasar

5. Membedakan serta mengunggulkan produk dibanding produk pesaing

6. Membentuk citra produk di mata konsumen sesuai dengan yang diinginkan.
7. Mengubah tingkah laku dan pendapat konsumen

\subsection{Algoritma Apriori}

Algoritma apriori adalah adalah algoritma yang paling terkenal untuk menemukan pola frekuensi tinggi. algoritma apriori dibagi menjadi beberapa tahap yang disebut narasi atau pass Pembentukan kandidat itemset, kandidat k-itemset dibentuk dari kombinasi (k-1)-itemset yang didapat dari iterasi sebelumnya. Satu cara dari algoritma apriori adalah adanya pemangkasan kandidat k-itemset yang subset-nya yang berisi (k-1) item tidak termasuk dalam pola frekuensi tinggi dengan panjang k-1.(Buulolo, 2017)

Algoritma apriori adalah salah satu algoritma yang melakukan pencarian frequent itemset dengan menggunakan teknik association rule. Untuk mencari association rule dari suatu kumpulan data, tahap pertama yang harus dilakukan adalah mencari frequent itemset terlebih dahulu. Frequent itemset adalah sekumpulan item yang sering muncul secara bersamaan. Penting tidaknya suatu asosiasi dapat diketahui dengan dua tolak ukur, yaitu support dan confidence. Support adalah nilai penunjang atau persentase kombinasi sebuah item dalam database, sedangkan confidence adalah nilai kepastian yaitu kuatnya hubungan antar item dalam aturan asosiasi. Proses utama yang dilakukan dalam algoritma apriori untuk mendapat frequent itemset.(Santoso, Hariyadi, \& Prayitno, 2016) yaitu :

1. Join (penggabungan).

Proses ini dilakukan dengan cara pengkombinasian item dengan yang item lainya hingga tidak bisa terbentuk kombinasi lagi.

2. Prune (pemangkasan).

Proses pemangkasan yaitu hasil dari item yang telah dikombinasikan kemudian dipangkas dengan menggunakan minimum support yang telah ditentukan.

Analisis asosiasi atau association rule mining adalah teknik data mining untuk menemukan aturan asosiasi antara kombinasi item. Contoh dari aturan asosiasi dari analisa pembelian di suatu pasar swalayan adalah 
dapat diketahui berapa besar kemungkinan seseorang membeli roti bersamaan dengan susu. Dengan pengetahuan tersebut pemilik mini market dapat mengatur penempatan barangnya atau merancang kampanye pemasaran dengan memakai kupon diskon untuk kombinasi barang tertentu.

Adapun metodologi dasar analisis asosiasi adalah sebagai berikut :

1. Analisis Pola Frekuensi Tinggi Tahapan ini mencari kombinasi item yang memenuhi syarat minimum dari nilai support dalam database. Nilai support sebuah item diperoleh dengan rumus berikut.

\section{Support A $=\underline{\text { Jumlah Transaksi Mengandung A }}$} Total Transaksi

Rumus 2.1 Menghitung nilai 1(satu) item support

Sedangkan nilai support dari 2 item diperoleh dari rumus 2 berikut.

$$
\text { Support }(\mathrm{A}, \mathrm{B})=\frac{\sum \text { Transaksi Mengandung A dan B }}{\Sigma \text { Transaksi }}
$$

Rumus 2.2 Menghitung nilai 2 item support

Pembentukan Aturan Asosiasi Setelah semua pola frekuensi tinggi ditemukan, barulah dicari aturan asosiasi yang memenuhi syarat minimum untuk confidence dengan menghitung confidence aturan asosiasif " jika A maka B ".Nilai confidence dari aturan " jika A maka B “ diperoleh dari rumus berikut.

\section{METODE PENELITIAN}

Untuk kerangka kerja ini dilakukan beberapa tahapan-tahapan yang harus dilaksanakan mulai dari awal sampai hasil akhir. Adapun tahapan kerja digambarkan dengan SDLC model waterfall seperti gambar sebagai berikut

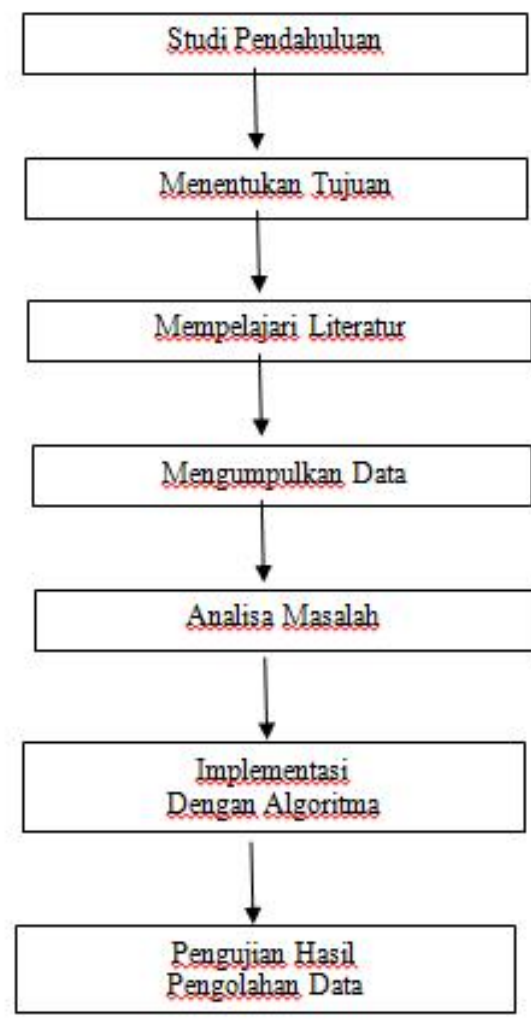

1. Studi Pendahuluan

Penelitian ini langsung dilakukan di lapangan atau di PT. Bandar madani batam.

2. Menentukan Tujuan

Tujuan penelitian merupakan tahap penliaian berdasarkan data 1 tahun penjualan untuk menentukan potensi kapan sebaiknya dilakukan promosi oleh PT.bandar madani batam menggunakan metode market base analisis.

3. Mempelajari Literatur

Pada tahapan ini melakukan analisa serta merancang beberapa variabel dan ketentuan yang akan di inputkan kedalam pengolahan data mining mengunakan metode market base analisis.

4. Mengumpulkan data

Pengumpulan data tentang penelitian ini dilakukan di perpustakaan Universitas Putera 
Batam dan data penjualan setahun miliki PT.Bandar Madani Batam

5. Analisa Masalah

Setelah dari tahapan literatur, penulis melanjutkan ke tahapan analisis serta ketentuan-ketentuan yang ada pada kelapa, dan mengelompokkan data yang penulis daapatkan agar data tersebut dapat diproses pada program dan mengujinya.

6. implementasi Dengan Algoritma Hasil dari pengolahan data tersebut maka selanjutnya dilakukan analisis untuk dibuatkan rancangan alur. Tahapan selanjutnya menggunakan metode market base analisis

7. Pengujian Akhir

Tahapan akhir yang peneliti lakukan untuk mengetahui apakah analisa yang sudah dirancang tersebut sesuai dengan yang peneliti harapkan, dan membandingkan dengan sistem yang masih menggunakan pola manual.

\section{HASIL PENELITIAN}

Untuk melakukan proses pengolahan data transaksi penjualan tiket pesawat pada PT.bandar madani dengan menggunakan data transaksi penjualan yang jumlahnya semakin banyak, maka akan dilakukan Analisis Asosiasi algoritma apriori dengan membuat nilai support.dengan menggunakan data transaksi penjualan seperti berikut :
Tabel 4.1 Transaksi

\begin{tabular}{|c|c|c|c|c|}
\hline Transaksi & \multicolumn{4}{|c|}{ Item yang dijual } \\
\hline Jakarta & Garuda & citilink & Lion & Sriwiiaya \\
\hline Medan & Citilink & Lion & Batik & \\
\hline Padang & Cililink & Lion & & \\
\hline Pontianak & Sriwijaya & Lion & Citilink & \\
\hline Bali & Citilink & Garuda & & \\
\hline Palembang & Citilink & Stiwijaya & Wings & \\
\hline Pckanbaru & Lion & Citilink & & \\
\hline Bandung & Lion & & & \\
\hline Yogiakarta & Lion & Wings & & \\
\hline Surabaya & Garuda & Lion & & \\
\hline
\end{tabular}

Data transaksi pada tabel 4.1 di bentuk tabel tabular yang akan mempermudah dalam mengetahui berapa banyak item yang ada dibeli dalam setiap transaksi seperti pada tabel berikut:

Tabel 4.2 Format Tabular Data Transaksi

\begin{tabular}{ccccccc}
\hline $\begin{array}{c}\text { Tran } \\
\text { saksi }\end{array}$ & $\begin{array}{c}\text { Gar } \\
\text { uda }\end{array}$ & $\begin{array}{c}\text { on } \\
\text { on }\end{array}$ & $\begin{array}{c}\text { Citi } \\
\text { link }\end{array}$ & $\begin{array}{c}\text { Sriw } \\
\text { ijaya }\end{array}$ & $\begin{array}{c}\text { Ba } \\
\text { tik }\end{array}$ & $\begin{array}{c}\text { Wi } \\
\text { ngs }\end{array}$ \\
\hline 1 & 1 & 1 & 1 & 1 & 0 & 0 \\
2 & 0 & 1 & 1 & 0 & 1 & 0 \\
3 & 1 & 1 & 1 & 0 & 1 & 1 \\
4 & 0 & 1 & 1 & 1 & 0 & 0 \\
5 & 1 & 0 & 1 & 0 & 1 & 1 \\
6 & 0 & 0 & 1 & 1 & 0 & 1 \\
7 & 1 & 1 & 1 & 0 & 0 & 0 \\
8 & 0 & 1 & 0 & 1 & 1 & 0 \\
9 & 1 & 0 & 0 & 0 & 0 & 1 \\
10 & 1 & 1 & 0 & 1 & 1 & 0 \\
\hline Juml & & & & & & \\
ah & $\mathbf{6}$ & $\mathbf{7}$ & $\mathbf{7}$ & $\mathbf{5}$ & $\mathbf{5}$ & $\mathbf{4}$ \\
\hline
\end{tabular}




\subsection{Pembentukan itemset}

Berikut ini adalah penyelesaian berdasarkan kasus yang sudah disediakan pada tabel 4.2 Proses pembentukan C1 atau disebut dengan 1 itemset dengan jumlah dengan rumus sebagai berikut:

\section{Support A $=\underline{\text { Jumlah Transaksi Mengandung A }}$ Total Transaksi}

1. Support (Garuda) $=\frac{6}{10}=0.6$

2. Support Lion $=\frac{7}{10}=0.7$

3. Support Citilink $=\frac{7}{10}=0.7$

4. Support (Sriwijaya) $=\frac{5}{10}$

$$
=0.5
$$

5. Support $($ Batik $)=\frac{5}{10}=0.5$

6. Support (Wings) $=\frac{4}{10}=0.4$

Hasil dari perhitungan diatas diubah kedalam bentuk persentase untuk mengetahui confidence dari masing-masing item penjualan, hasil tersebut dapat kita lihat pada tabel berikut :

Tabel 4.3 Support Setiap Item

\begin{tabular}{cccc}
\hline Kode & Item & Jumlah & Confidence \\
\hline 1 & Garuda & 6 & $60 \%$ \\
2 & Lion & 7 & $70 \%$ \\
3 & Citilink & 7 & $70 \%$ \\
4 & Sriwijaya & 5 & $50 \%$ \\
5 & Batik & 5 & $50 \%$ \\
6 & Wings & 4 & $40 \%$ \\
\hline
\end{tabular}

Dari proses pembentukan itemset pada

Dari proses pembentukan itemset pada tabel 4.3. hasil pembentukan 1 itemset akan dilakukan kombinasi 2 itemset

\subsection{Kombinasi 2 itemset}

Proses pembentukan $\mathrm{C} 2$ atau disebut dengan 2 itemset dengan rumus:

$$
\text { Support }(\mathrm{A}, \mathrm{B})=\frac{\sum \text { Transaksi Mengandung A dan B }}{\Sigma \text { Transaksi }}
$$

Tabel 4.42 Itemset

\begin{tabular}{llc} 
Nama Item & Set & Jumlah \\
\hline Garuda & Lion & 4 \\
Garuda & Citilink & 4 \\
Garuda & Sriwijaya & 2 \\
Garuda & Batik & 3 \\
Garuda & Wings & 3 \\
Lion & Citilink & 5 \\
Lion & Sriwijaya & 4 \\
Lion & Batik & 4 \\
Lion & Wings & 1 \\
Citilink & Batik & 3 \\
Citilink & Wings & 3 \\
Citilink & Sriwijaya & 3 \\
Sriwijaya & Batik & 2 \\
Sriwijaya & Wings & 1 \\
Batik & Wings & 2
\end{tabular}

Dari tabel tersebut di atas, ditetapkan nilai $\varnothing=3$ sehingga didapat $\mathrm{C} 2=$ (Garuda,Lion) (Garuda,Batik) (Garuda,Wings) (Garuda, Citilink), (Lion, Citilink) (Citilink,Batik) (Citilink,Wings) (Citilink,Sriwijaya) (Lion, Sriwijaya) (Lion,Batik).

\subsection{Kombinasi 3 itemset}

Kombinasi dari itemset pada C2 bisa digabungkan menjadi 3 itemset. Proses pembentukan C3 atau disebut dengan 3 itemset dapat dilihat dari tabel dibawah ini : 
Tabel 4.5 Kombinasi 3 itemset

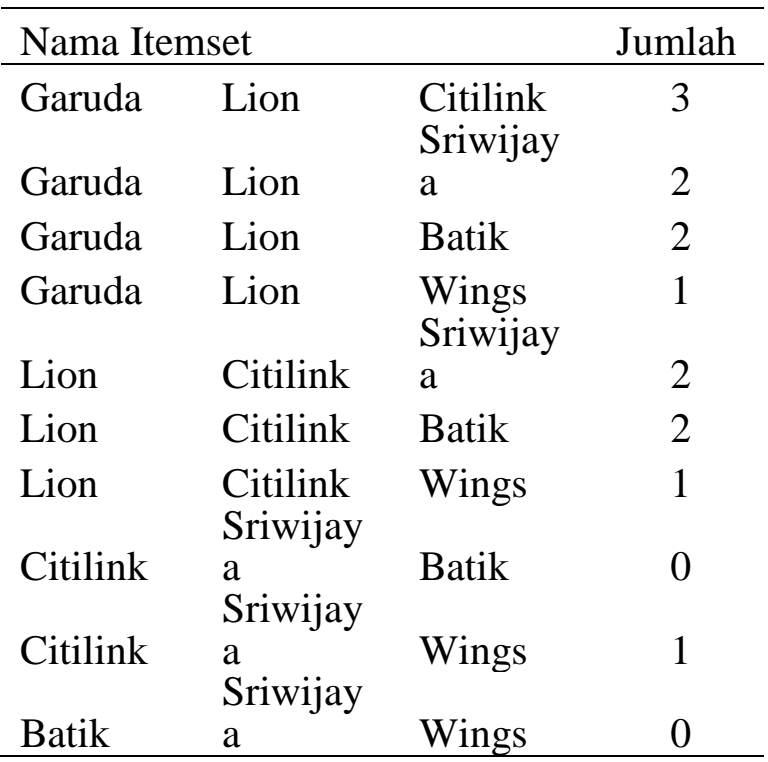

Dengan demikian, C3 = (Garuda,Lion,Citilink $)$ karena hanya kombinasi itulah yang memiliki frekuensi kemunculan $>=\varnothing$.

\subsection{Pembentukan Aturan Asosiasi}

Setelah pola frekuensi tinggi ditemukan, kemudian dicari aturan asosiasi yang memenuhi syarat minimum untuk confidence dengan menghitung confidence aturan asosiatif $\mathrm{A} \rightarrow \mathrm{B}$, nilai confidence dari aturan $\mathrm{A} \rightarrow \mathrm{B}$ dapat dirumuskan sebagai berikut:

\section{Confidence $P(B \mid A)=\sum$ Transaksi Mengandung A dan B $\sum$ Transaksi Mengandung A}

1. Confidence $\mathrm{P}$ Garuda|Lion $=\frac{4}{6}=0.66$

2. Confidence $P$ Garuda|Citilink $=\frac{4}{6}$

$$
=0.66
$$

3. Confidence $\mathrm{P}$ Lion $\mid$ Citilink $=\frac{5}{7}=0,715$

Dari C3 yang telah ditemukan, bisa dilihat besarnya nilai Support dan Confidence dari aturan asosiasi seperti tabel dibawah ini :
Tabel 4.6 Aturan Asosiasi dari C 3

\begin{tabular}{lll}
\hline \multirow{2}{*}{ Rule } & \multicolumn{2}{l}{ Confiden } \\
& ce \\
\hline Jika Beli Garuda ,Lion maka & $4 /$ & 66.0 \\
akan beli Citilink & 6 & $0 \%$ \\
Jika Beli Garuda,Citilink maka & $4 /$ & 66.0 \\
akan beli Lion & 6 & $0 \%$ \\
Jika Beli Lion,Citilink Maka & $5 /$ & 71.5 \\
akan beli Garuda & 7 & $0 \%$ \\
\hline
\end{tabular}

Berdasarkan tabel 4.6 nilai confidence minimal adalah $71 \%$ sehingga aturan yang bisa terbentuk adalah aturan dengan antecedent berikut :

- Jika Beli lion,Citilink maka akan beli Garuda

Sementara itu aturan asosiasi untuk C2 bisa dilihat pada tabel berikut :

Tabel 4.7 Aturan Asosiasi dari C2

\begin{tabular}{|c|c|c|}
\hline \multirow{2}{*}{$\begin{array}{l}\text { Rule } \\
\text { Jika beli Garuda maka beli lion }\end{array}$} & \multicolumn{2}{|c|}{$\begin{array}{l}\text { Confidenc } \\
\mathrm{e}\end{array}$} \\
\hline & $4 / 6$ & $66 \%$ \\
\hline Jika beli lion maka beli garuda & $4 / 7$ & $57 \%$ \\
\hline $\begin{array}{l}\text { J1ka beli Garuda maka bel1 } \\
\text { citilink }\end{array}$ & $4 / 6$ & $66 \%$ \\
\hline $\begin{array}{l}\text { Jika beli citilink maka beli } \\
\text { garuda }\end{array}$ & $4 / 7$ & $57 \%$ \\
\hline Jika beli lion maka beli citilink & $5 / 7$ & $71 \%$ \\
\hline Jika beli citilin & $5 / 7$ & $71 \%$ \\
\hline $\begin{array}{l}\text { Jika beli } \\
\text { Sriwijaya }\end{array}$ & $4 / 7$ & $57 \%$ \\
\hline Jika beli sriwijaya maka beli & & \\
\hline lion & $4 / 5$ & $80 \%$ \\
\hline Jika beli Lion maka beli batik & $4 / 7$ & $57 \%$ \\
\hline Jika beli batik maka beli lion & $4 / 5$ & $80 \%$ \\
\hline
\end{tabular}

Sementara itu aturan asosiasi final secara berurut dengan nilai confidence minimal adalah $70 \%$ dapat dilihat pada tabel berikut. 
Tabel 4.8 Aturan Asosiasi Final

\begin{tabular}{lll}
\hline & \multicolumn{2}{l}{ Confidenc } \\
Rule & e & \\
\hline Jika beli lion maka beli citilink & $5 / 7$ & $71 \%$ \\
Jika beli citilink maka beli lion & $5 / 7$ & $71 \%$ \\
Jika beli sriwijaya maka beli & & \\
lion & $4 / 5$ & $80 \%$ \\
Jika beli batik maka beli lion & $4 / 5$ & $80 \%$ \\
\hline
\end{tabular}

Tiket yang paling sering dibeli oleh konsumen adalah Sriwijaya,Lion dan Batik dengan diketahuinya barang yang paling sering dibeli pelanggan, maka pihak travel agen dapat menyusun strategi dalam penentuan promo maskapai untuk menyusun strategi pemasaran pesawat lainnya. Jadi dapat dibuat aturan dari hasil di atas adalah : jika membeli tiket sriwijaya maka akan membeli tiket lion dengan support $40 \%$ dan confidence sebesar $80 \%$, jika membeli tiket batik maka membeli tiket lion dengan nilai support $40 \%$ dan confidence sebesar $80 \%$

\section{DAFTAR PUSTAKA}

Aghdam, A. R., Kamalpour, M., Chen, D., Tze, A., \& Sim, H. (2013). Finding Interesting Places at Malaysia: A Data Mining Perspective, 89-93.

Aldeen, Y. A. A. S., Salleh, M., \& Razzaque, M. A. (2015). A comprehensive review on privacy preserving data mining. SpringerPlus, $4(1), \quad 694$. https://doi.org/10.1186/s40064-0151481-X

Arief, A., Widyawan, \& Sunafri Hantono, B. (2012). Rancang Bangun Sistem Rekomendasi Pariwisata Mobile dengan Menggunakan Metode Collaborative Filtering dan Location Based Filtering. Jnteti, $\quad$ 1(3). https://doi.org/10.22146/JNTETI.V1I3.1 29

Buulolo, E. (2017). ImplementasiI Algoritma Apriori Pada Sistem Persediaan Obat ( Studi Kasus: Apotik Rumah Sakit Estomihi ).

Chan, A. S. (2018). Jurnal Ilmiah Informatika ( JIF ) Prediksi Kedatangan Wisatawan Pada Pariwisata Kota Batam Dengan Menggunakan Teknik Knowledge Data
Discovery, 1-6.

Data, A., Untuk, M., Pola, M., Gerakan, A., Berdasarkan, V., Object, R., ... Kinect, M. K. (2014). Fakultas Ilmu Komputer Universitas Narotama Surabaya Fakultas Ilmu Komputer Universitas Narotama Surabaya, 21(2).

Gunadi, G., \& Sensuse, D. I. (2012).

Penerapan Metode Data Mining Market Basket Analysis Terhadap Data Penjualan Produk Buku Dengan Menggunakan Algoritma Apriori Dan Frequent Pattern Growth ( FPGROWTH ), 4(1).

Magister, P., Gunadarma, U., Studi, P., Sistem, T., \& Guandarma, U. (2009). Personifikasi Web E-Commerce Menggunakan Basket Algoritma Dari Data Mining, 3, 21-22.

Santoso, H., Hariyadi, I. P., \& Prayitno. (2016). Data Mining Analisa Pola Pembelian Produk. Teknik Informatika, (1), 19-24.

Singkil, K. A. B. A. (2015). Sistem Pendukung Keputusan Pengangkatan Karyawan Tetap Dengan Metode Analytic Hierarchy Process ( Ahp ) Pada Pt . Perkebunan Lembah Bhakti Propinsi Nad, (April), 96-106.

Sugandi. (2013). Pengaruh Kepuasan Kerja Dan Loyalitas Kerja Terhadap Organizational Citizenship Behavior Pada Karyawan Pt . Surya Timur Sakti Jatim. Jurnal Agora, 1(1), 5-10. 